ORIGINAL ARTICLE

\title{
A Clinical Analysis of the Medicolegal Cases Presented at Khawaja Muhammad Safdar Medical College, Sialkot
}

\author{
USMAN SHAHID BUTT ${ }^{1}$, KANWAL ZAHRA ${ }^{2}$, MARYAM SHAHID ${ }^{3}$ \\ ${ }^{1}$ Forensic Medicine \& Toxicology, Department of Govt. Khawaja Muhammad Safdar Medical College, Sialkot, Pakistan \\ ${ }^{2}$,Forensic Medicine \& Toxicology, Department of King Edward Medical University, Lahore, Pakistan. \\ Correspondence to: Usman Shahid Butt, Email: buttrulez@gmail.com
}

\begin{abstract}
Objective: To determine the clinical pattern of the medicolegal cases presented at Khawaja Muhammad Safdar Medical College, Sialkot

Material and Methods: It was a retrospective Hospital based cross-sectional study, which was conducted at medicolegal clinic of government Khawaja Muhammad Safdar Medical College, Sialkot. All the cases those, who were presented at emergency department (medicolegal clinic) with history of industrial injuries, Road traffic accidents, burns, Assault, Falls and Poisoning and others with either of age and gender were included. This analysis was of one year from January 2020 to December 2020. All the data was recorded via self-made study proforma and analyzed by using SPSS version 20.

Results: A total of 1079 medicolegal incidents were analysed. Out of all blunt injury, sharp weapon injury, poisoning, acid intake and road traffic incidences were found to be commonest as $27.20 \%, 20.60 \%, 15.60 \%$, $12.40 \%$ and $10.20 \%$ respectively. Blunt injuries, sharp weapon injuries, gunshot injuries and alcohol intake incidences were significantly higher among males and poisoning and acid intake incidences were significantly high among females $(p-<0.05)$. Blunt injuries, sharp weapon injuries, alcohol and poisoning events were seen significantly high almost during winter season from January to march ( $p-0.001)$.

Conclusion: In the study conclusion, blunt injury, sharp weapon injury, poisoning, acid intake and road traffic incidences were observed to be the commonest medicolegal incidences. These events mostly observed during January to March duration. However blunt injuries, sharp weapon injuries, gunshot injuries and alcohol intake incidences were mostly observed among males, while poisoning and acid intake incidences among females.
\end{abstract}

Keywords: Medicolegal events, gender, season

\section{INTRODUCTION}

Medico-legal cases remain important aspect of medical practice that medical officers encounter in the emergency room frequently. ${ }^{1}$ Hurts, injuries, and wounds come in a variety of forms, but they most commonly occur due to assaults. By definition, assault refers to the threat or force applied to another's body in a hostile or angry manner, whereas battery refers to when the assaults are completed and somebody has actually implemented force on to the victim's body. ${ }^{2,3}$ All incidents that indicate to a probable criminal behaviours, such as gunshot injuries, injuries caused by a sharp or blunt-edged weapons, homicide, sexual assault, and poisoning, fall into the term "medicolegal cases"., 4,5 Management of medicolegal cases is important in clinical practice and make up a significant portion of emergency medical situations. " A case is termed as "medicolegal" if the attending doctor, after taking the patient's history and evaluating him or her, believes that the law enforcement agency should be involved in order to maintain and hold accountability of the case. ${ }^{6,7}$ Medico-legal incidents make up a large portion of the emergencies referred to all teaching hospitals' casualty departments, which are the basis for dealing with all such instances. The administration of medical and legal services in such situation's accounts for a significant percentage of the hospital's workload.6,8 Although this study has been conducted to determine the clinical pattern of the medicolegal cases presented at Khawaja Muhammad Safdar Medical College, Sialkot.

\section{MATERIAL AND METHODS}

It was a retrospective Hospital based cross-sectional study, which was conducted at medicolegal clinic of government Khawaja Muhammad Safdar Medical College, Sialkot. All the cases those, who were presented at emergency department (medicolegal clinic) with history of industrial injuries, Road traffic accidents, burns, Assault, Falls and Poisoning and others with either of age and gender were included. All the non-medicolegal patients were excluded from the study. This analysis was of one year from January 2020 to December 2020. All the data was collected in terms of age, gender and type of the events declared as per medicolegal record. All the data was recorded via selfmade study proforma. Data was analyzed by using SPSS version 20 . Numerical variable like age was analyzed in form of mean and standard deviation. Categorical variables like gender and type of incident were computed in the form of frequency and percentage. Type of the incidents were subjected to were discriminates between both genders by applying the chi-square test and a $p$-value $\leq 0.05$ was considered as significant.

\section{RESULTS}

A total of 1079 medicolegal incidents were analysed. Out of all blunt injury, sharp weapon injury, poisoning, acid intake and road traffic incidences were found to be commonest as $27.20 \%, \quad 20.60 \%, \quad 15.60 \%, \quad 12.40 \%$ and $10.20 \%$ respectively as showed in figure 1 .

Blunt injuries, sharp weapon injuries, gunshot injuries and alcohol intake incidences were significantly higher 
among males $(\mathrm{p}-<0.05)$, while poisoning and acid intake incidences were significantly high among females $(p-$ $<0.05$ ), however other medicolegal incidences were statistically insignificant according to gender $(p->0.05)$ as showed in table.1

Blunt injuries, sharp weapon injuries, alcohol and poisoning events were seen significantly high almost during winter season from January to march ( $p-0.001)$, while rest of the events were statistically insignificant as per monthly analysis as showed in table.2

\section{Frequency of overall incidents}

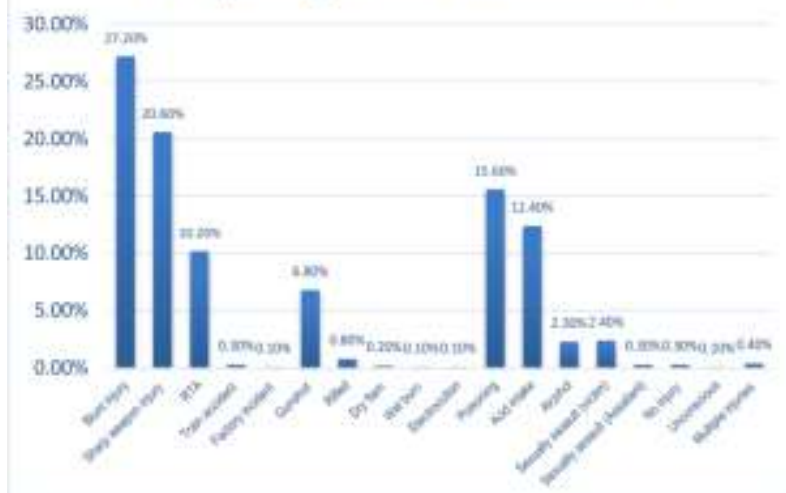

Fig 1: Frequency of overall medicolegal incidences $n=1097$
Table.1 Medicolegal incidents according to gender

\begin{tabular}{|c|c|c|c|c|}
\hline \multirow{2}{*}{ Variables } & \multicolumn{2}{|c|}{ Gender } & \multirow[b]{2}{*}{ Total } & \multirow[b]{2}{*}{$p$-value } \\
\hline & Male & Female & & \\
\hline Blunt injury & 188 & 105 & 293 & 0.001 \\
\hline Sharp weapon injury & 121 & 101 & 222 & 0.058 \\
\hline RTA & 66 & 44 & 110 & 0.274 \\
\hline Train accident & 03 & 0 & 03 & 0.121 \\
\hline Factory incident & 01 & 0 & 01 & 0.372 \\
\hline Gunshot & 47 & 26 & 73 & 0.054 \\
\hline Rifled & 07 & 02 & 09 & 0.177 \\
\hline Dry flam & 01 & 01 & 02 & 0.877 \\
\hline Wet burn & 0 & 01 & 01 & 0.261 \\
\hline Electrocution & 0 & 01 & 01 & 0.261 \\
\hline Poisoning & 66 & 102 & 168 & 0.001 \\
\hline Acid intake & 26 & 108 & 134 & 0.001 \\
\hline Alcohol & 25 & 0 & 25 & 0.001 \\
\hline Sexually assault (victim) & 13 & 13 & 26 & 0.542 \\
\hline Sexually assault (Assailant) & 03 & 0 & 03 & 0.121 \\
\hline No injury & 02 & 01 & 03 & 0.701 \\
\hline Unconscious & 01 & 00 & 01 & 0.372 \\
\hline Multiple injuries & 03 & 01 & 04 & 0.435 \\
\hline
\end{tabular}

Table.2 Medicolegal incidents according to monthly basis

\begin{tabular}{|c|c|c|c|c|c|c|c|c|c|c|c|c|c|c|c|}
\hline \multirow{2}{*}{\multicolumn{2}{|c|}{ Medicolegal incidence }} & \multicolumn{13}{|c|}{ Months } & \multirow{2}{*}{$\begin{array}{l}p- \\
\text { value }\end{array}$} \\
\hline & & Jan & Feb & Mar & April & May & June & July & Aug & Sep & Oct & Nov & Dec & Total & \\
\hline \multicolumn{2}{|l|}{ Blunt injury } & 39 & 27 & 33 & 24 & 19 & 19 & 23 & 26 & 31 & 18 & 16 & 18 & 293 & 0.001 \\
\hline \multicolumn{2}{|l|}{ Sharp weapon } & 26 & 30 & 18 & 19 & 14 & 20 & 15 & 20 & 15 & 15 & 14 & 16 & 222 & 0.001 \\
\hline \multicolumn{2}{|l|}{ RTA } & 19 & 5 & 17 & 10 & 6 & 8 & 5 & 10 & 12 & 6 & 6 & 6 & 110 & 0.431 \\
\hline \multicolumn{2}{|l|}{ Train accident } & 1 & 0 & 0 & 0 & 1 & 0 & 0 & 0 & 0 & 0 & 0 & 1 & 3 & 0.503 \\
\hline \multicolumn{2}{|l|}{ Factory Incident } & 0 & 0 & 1 & 0 & 0 & 0 & 0 & 0 & 0 & 0 & 0 & 0 & 1 & 0.934 \\
\hline \multicolumn{2}{|l|}{ Gunshot } & 6 & 6 & 5 & 5 & 7 & 11 & 6 & 6 & 5 & 4 & 6 & 6 & 73 & 0.018 \\
\hline \multicolumn{2}{|l|}{ Rifled } & 1 & 1 & 0 & 0 & 0 & 0 & 1 & 1 & 1 & 1 & 2 & 1 & 9 & 0.539 \\
\hline \multicolumn{2}{|l|}{ Dry flame } & 2 & 0 & 0 & 0 & 0 & 0 & 0 & 0 & 0 & 0 & 0 & 0 & 2 & 0.254 \\
\hline \multicolumn{2}{|l|}{ Wet burn } & 0 & 0 & 0 & 0 & 1 & 0 & 0 & 0 & 0 & 0 & 0 & 0 & 1 & 0.152 \\
\hline \multicolumn{2}{|l|}{ Electrocution } & 0 & 0 & 0 & 0 & 0 & 0 & 0 & 0 & 0 & 0 & 1 & 0 & 1 & 0.071 \\
\hline \multicolumn{2}{|l|}{ Poisoning } & 30 & 14 & 10 & 12 & 16 & 14 & 12 & 10 & 11 & 10 & 10 & 19 & 168 & 0.001 \\
\hline \multicolumn{2}{|l|}{ Acid intake } & 7 & 11 & 11 & 14 & 10 & 10 & 18 & 12 & 12 & 10 & 8 & 11 & 134 & 0.001 \\
\hline \multicolumn{2}{|l|}{ Alcohol } & 10 & 1 & 3 & 2 & 0 & 0 & 0 & 2 & 0 & 1 & 4 & 2 & 25 & 0.008 \\
\hline \multirow[t]{2}{*}{ Sexual assault } & Victim & 3 & 3 & 2 & 3 & 3 & 3 & 2 & 1 & 1 & 1 & 1 & 3 & 26 & \multirow[t]{2}{*}{0.001} \\
\hline & Assailant & 0 & 0 & 0 & 0 & 1 & 0 & 1 & 1 & 0 & 0 & 0 & 0 & 3 & \\
\hline \multirow[t]{3}{*}{ Miscellaneous } & No injury & 0 & 0 & 1 & 0 & 0 & 0 & 0 & 0 & 0 & 1 & 0 & 1 & 3 & \multirow[t]{3}{*}{0.001} \\
\hline & Unconscious & 0 & 0 & 0 & 1 & 0 & 0 & 0 & 0 & 0 & 0 & 0 & 0 & 1 & \\
\hline & Multiple injuries & 0 & 0 & 0 & 4 & 0 & 0 & 0 & 0 & 0 & 0 & 0 & 0 & 4 & \\
\hline
\end{tabular}

\section{DISCUSSION}

A big constitution of the load of work medical site and institutes consists of the legal and the clinical facilities that are provoking to organize to medico-legal episodes. ${ }^{4}$ In this study the blunt injury, sharp weapon injury, poisoning, acid intake and road traffic incidences were found to be commonest as $27.20 \%, 20.60 \%, 15.60 \%, 12.40 \%$ and $10.20 \%$ respectively. Similarly, Altaf $\mathrm{R}$ et $\mathrm{al}^{4}$ reported that among commonest medicolegal events, the blunt injuries were, $31.33 \%$ road traffic accident events were $39.33 \%$ and sharp weapon injuries were 18.67\%. In another international study the prevalence of penetrating trauma was most common $86.8 \%$ in medicolegal events followed by $13.3 \%$ of firearm injuries $13.3 \%$. Consistently Cheema $\mathrm{TN}$ et $\mathrm{al}^{10}$ demonstrated that the cases of blunt trauma were most common $55 \%$, followed by sharp-edged weapon incidents were $28 \%$, sexual assault events were $7 \%$, poisoning cases were 3\% and firearms injuries were $2 \%$. Yogesh $\mathrm{G}$ et $\mathrm{al}^{11}$ reported that most common medico legal events were physical trauma, suicide, and sexual assault. 
However, the Malik $\mathrm{R}$ et $\mathrm{al}^{6}$ conducted the study at tertiary care Hospital of Rawalpindi, and reported that the commonest medicolegal events were of RTA these findings were in contrast with our study. On other hand the Malik $Y$ et $\mathrm{al}^{13}$ stated in their study the most common cases seen at casualty of poisoning and these findings were also vary from current study. Our findings were also differing from the findings of Hussain $\mathrm{SN}$ et $\mathrm{al}^{14}$, who demonstrated that the burnt medicolegal events were most common. The above difference in medicolegal events may because of small and large sample size and selection criteria of the studies and this may because of seasonal variations as in this study Blunt injuries, sharp weapon injuries, alcohol and poisoning events were seen significantly high almost during winter season from January to march ( $p-0.001)$.

In this study males were mostly seen among medicolegal events and these findings were similar to the study of Seema $\mathrm{N}$ et $\mathrm{al}^{2}$ as the out of all cases males were $87.3 \%$ and females were $12.7 \%$. Altaf $\mathrm{R}$ et $\mathrm{al}^{4}$ also found males in majority $59.3 \%$ as compared to females $40.9 \%$. In an Indian study of Siddappa SC et al $^{12}$ reported that, out of all study subjects' males were $71.76 \%$ and females were $28.23 \%$. This male pre-Domenici may because of in Pakistan and Indian countries the males were mostly involved in outdoor activities specially in road traffic and weapon association.

In this study the blunt injuries, sharp weapon injuries, gunshot injuries and alcohol intake incidences were significantly higher among males $(p-<0.05)$, while poisoning and acid intake incidences were significantly high among females $(p-<0.05)$. Similar findings were seen in the study of Malik $R$ et $a^{6}$ as blunt injuries, RTA, sharp weapon injuries and Firearm injuries were commonest among males and poisoning events were commonest among females. Although in the study of Kulkarni $\mathrm{P}$ et $\mathrm{al}^{15}$ stated that the higher percentage of males were involved in medico legal cases as $72.33 \%$ and $27.67 \%$ females.

\section{CONCLUSION}

In the study conclusion, blunt injury, sharp weapon injury, poisoning, acid intake and road traffic incidences were observed to be the commonest medicolegal incidences. These events mostly observed during January to March duration. However blunt injuries, sharp weapon injuries, gunshot injuries and alcohol intake incidences were mostly observed among males, while poisoning and acid intake incidences among females. As the blunt injury, sharp weapon injury, poisoning and RTA events are the most differentiating episodes of the study, hence the proper enactment of the relevant laws are needed today.

\section{REFERENCES}

1. Ahmed B, Alam MS, Islam MT, Ahmed SM, Uddin T, Islam MJ, Khasru MR. Scholars Journal of Applied Medical Sciences. hernia. 2020;7(15.2):15-2.

2. Seema N, Ahmad I, Mughal S, Khan D, Khan O. Frequency And Types of Bodily Medico-Legal Injuries in a Rural Area. Journal of Ayub Medical College Abbottabad. 2010 Jun 1;22(2):93-5.

3. Ahmad I, Seema N, Shafi S, Salim M. Frequency and types of bodily medico-legal injuries in an urban area. J Ayub Med Coll Abbottabad. 2012;24(3-4):117-9.

4. Altaf R, Shaikh MR, Memon AA, Pirya N, Malik F, Jogi MA. Medico-Legal Cases (MLC) Presented at a Tertiary Care Center and Acute Symptoms of Post-Traumatic Stress Disorder among the Survivors. Pakistan Journal Of Neurological Surgery. 2021 Jun 25;25(2):263-70.

5. Sandeep KS, Ranjit TM, Deshpande VL, Dilip WR. Profile of Medico-Legal cases at a Tertiary Care Hospital in Ahmed Nagar, Maharashtra. Indian J. Forensic Med. Pathol. $2015 ; 1 ; 8(4): 113$.

6. Malik R, Atif I, Rashid F, Abbas M. An analysis of 3105 medico legal cases at tertiary care hospital, Rawalpindi. Pakistan journal of medical sciences. 2017 Jul;33(4):926.

7. Siddappa SC, Datta A. A Study Pattern of Medico-legal Cases Treated at a Tertiary Care Hospital in Central Karnataka. Indian J Forensic Comm Med. 2015;2(4):193-197

8. Timsinha S, Kar SM, Baral MP, Ranjitkar M. Profile of Pattern of Medico-Legal Cases in the Casualty of A Teaching Hospital of Western Region of Nepal. J Indian Acad Forensic Med. 2015;37(1):46-49.

9. Maguire M, McVie S. Crime data and criminal statistics: A critical reflection. Oxford: Oxford University Press; 2017;16389

10. Cheema TN, Qasim AP, Abaid T, Anjum H, Munir U, Abbas Q. Profile of Medicolegal Cases in the Rural Areas of District Bahawalpur. APMC 2019;13:104-7

11. Yogesh G. Profile of Medico-legal Cases Reported to Casualty of Medical College Hospital, Ballari Hyderbad Karnataka Region. Indian Journal of Forensic Medicine \& Toxicology. 2015 Jul 1;9(2).

12. Siddappa SC, Datta A. A study pattern of medico-legal cases treated at a tertiary care hospital in central Karnataka. Indian J Forensic Comm Med. 2015;2(4):193-7.

13. Malik Y, Chawla R, Sharma G, Malik P, Singh R, Tripathi A. Profile of Medico-legal Cases in Casualty of a Rural Medical College of Haryana. J Indian Acad Forensic Med. 2013;35(4):367-8

14. Hussaini SN, Kulkarni CS, Batra AK. Profile of medico-legal cases coming to casualty of Government Medical College, Akola. Journal of Forensic Medicine, science and Law. 2013;22(2).

15. Prakash Kulkarni\& R. K. Pandey ; Current Tends of Medico Legal Cases brought to Tertiary Hospital, Aurangabad India. IJCMAAS 2016, 9(2), 92-95 